Ann. Biol. anim. Bioch. Biophys., 1979, 19 (5), 1461-1468.

\title{
Qualitative changes in medium and large antral follicles in the human ovary during the menstrual cycle
}

\author{
par A. GOUGEON
}

Laboratoire de Physiologie de la Reproduction humaine, INSERM FRA 32,

Gynécologie Obstétrique, Hôpital Antoine Béclère, 92141 Clamart Cedex, France.

\begin{abstract}
Summary. To better understand human ovarian folliculogenesis, we analyzed 370 (medium an large) follicles from the ovaries of 33 women aged 18 to 50 years at various stages of the menstrual cycle. These follicles were grouped according to granulosa cell number. The criteria used for distinguishing between healthy and atretic follicles were the pyknotic index and the nuclear status of the oocyte, completed by other parameters of follicular involution. The mean mitotic index of the follicles did not vary with the stage of the menstrual cycle, except for those having between $0.37 \times 10^{6}$ and $2.5 \times 10^{6}$ granulosa cells during the late luteal phase. In humans, a species with a long follicular phase, the qualitative kinetics of medium and large antral follicles did not seem to support any particular theory of a wave of follicular development. It is suggested that follicular growth is a continuous process with privileged phases during the menstrual cycle, especially in the late luteal phase when medium antral follicles are less apt to involute and grow faster.
\end{abstract}

\section{Introduction.}

Human ovarian folliculogenesis is still quite incompletely known today despite work by Block (1951), Green and Zuckerman (1951), Sauramo (1954), Govan (1968, 1970), Starup and Visfeldt (1974), Breitenecker ef al. (1975), Mestwerdt ef al. (1977) on human follicular structure.

Block's conclusions (1951) are unfortunately too imprecise, and our knowledge of the profiles of plasma gonadotropins and of ovarian steroids during the human menstrual cycle has progressed greatly since then. A better understanding of human folliculogenesis appears to be necessary today in order to deal with some clinical situations. In the treatment of infertility it is very important to known the time of the menstrual cycle when follicular growth can best be stimulated to induce ovulation. It would also be useful to understand the origin of irregular ovulations sometimes related to intra-follicular overripeness of the oocyte, followed by spontaneous abortion (Fugo and Butcher, 1970 ; Bomsel-Helmreich, 1976) or monozygous twins (Bomsel-Helmreich and Papiernik-Berkhaver, 1973).

The present study, comparing the mitotic index, reports the growth rate pattern of medium and large antral folticles (from $1 \mathrm{~mm}$ in diameter) containing more than $0.075 \times 10^{6}$ granulosa cells. The qualitative development of the follicles in each folli- 
cular group is also analyzed throughout the human menstrual cycle by separating the healthy from the atretic follicles.

Using these findings, obtained on the freshly fixed ovaries of women with a well known reproductive history, we discuss the process of folliculogenesis in the women, a mammalian species having a long follicular phase.

\section{Material and methods.}

Sampling. - We used the ovaries of 33 women between the ages of 18 and 50 years, undergoing laparotomy for various gynecological disorders not directly related to ovarian pathology. They had all had regular menstrual cycles ( $28 \pm 2$ days).

The samples were taken over a theoretical menstrual cycle of 28 days, divided into six periods : early follicular : between day 1 (first day of menses) and about day 5 ; mid-follicular : between about day 6 and about day 10 ; late follicular : between about day 11 and ovulation; early luteal : between day 15 and about day 19 ; midluteal : between about day 20 and about day 24 ; late luteal : between about day 25 and day 28. The period range was determined according to day of last menses, endometrial histology when hysterectomy was performed, and sometimes steroid and gonadotropin levels in the peripheral blood. All the women had been ovulating during the preceding three or four cycles, as corroborated by histological observation of the previous corpora lutea.

Histological methods. - Whole (28) or largely biopsied (5) ovaries were freshly fixed in Bouin's or in AFA fluid, serially sectioned at $10 \mu$, and stained with Hemalunpicro-indigocarmin or Hematoxylin-Masson blue.

Follicular dimensions were measured with an ocular micrometer. The basement membrane of the follicle was taken at the outer limits of the follicle. Follicular diameter was the mean of three measurements : the mean of two measurements taken at right angles to each other on the section in which follicle area was maximum, and the number of sections in which the follicle was viewed multiplied by 50 .

To obtain the number of granulosa cells in the follicle, the volume of granulosa, in $\mathrm{mm}^{3}$ (taken as the difference between the sphere bounded by the inner surface of the granulosa and the sphere bounded by the basement membrane), was multiplied by the number of granulosa cells occupying a volume of $1 \mathrm{~mm}^{3}$.

The number of mitotic and pyknotic figures in the granulosa was counted on two or three sections; for each one, the number of granulosa cells (between 2000 for the smallest follicles and 20000 for the largest) was estimated by multiplying the volume (in $\mathrm{mm}^{3}$ ) of the granulosa tissue in that section by the number of granulosa cells occupying a volume of $1 \mathrm{~mm}^{3}$. The mitotic and pyknotic indexes are given for 1000 cells.

Classification of follicles. - The ovarian follicles were divided into 8 classes according to the total number of granulosa cells in each follicle. Only follicles with a differentiated theca interna, able to respond to gonadotropic stimulation, were considered (Eshkol and Lunenfeld, 1972 ; Goldenberg ef al., 1973). 
To estimate the time intervals involved in follicular growth, it is preferable to obiain the classes by doubling the granulosa cell number. But such a classification seemed complicated due to the large number of classes and the small number of follicles (370 medium and large antral follicles). It was thus decided to use classes obtained by quintupling granulosa cell number. Class 1 was defined as including follicles having between $0.6 \times 10^{3}$ and $3 \times 10^{3}$ granulosa cells, and so on (table 1 ).

TABLE 1

\begin{tabular}{cccc}
\hline Follicular class & $\begin{array}{c}\text { Number of follicular gra- } \\
\text { nulosa cells }\end{array}$ & $\begin{array}{c}\text { Mean follicular } \\
\text { diameter (in } \mu \mathrm{m})\end{array}$ & $\begin{array}{c}\text { Morphological } \\
\text { characteristics }\end{array}$ \\
\hline 1 & $0.6 \times 10^{3}$ to $3 \times 10^{3}$ & 120 & no antrum theca interna \\
\hline 2 & $3 \times 10^{3}$ to $15 \times 10^{3}$ & 350 & antrum formation \\
\hline 3 & $15+10^{3}$ to $75 \times 10^{3}$ & 1,000 & liftle antrum \\
\hline 4 & $75 \times 10^{3}$ to $375 \times 10^{3}$ & 2,000 & medium antrum \\
\hline 5 & $375 \times 10^{3}$ to $1.87 \times 10^{6}$ & 5,000 & medium antrum \\
\hline 6 & $1.87 \times 10^{6}$ to $9.4 \times 10^{6}$ & 10,000 & medium antrum \\
\hline 7 & $9.4 \times 10^{6}$ to $47 \times 10^{6}$ & 16,000 & large antrum \\
\hline 8 & $>47 \times 10^{6}$ & 22,000 & preovulatory
\end{tabular}

Atresia is scarce in follicles with little or no antrum (classes 1 to 3) (Gougeon, unpublished data), whereas it appeared quantitatively important and was especially correlated with the stage of the menstrual cycle in follicles larger than class 4. This suggests intra and/or extra-ovarian regulation in the growth of these follicles, and so only the medium and large antral follicles are considered in this report.

Distinction between healthy and atretic follicles. - Several criteria were used to distinguish between healthy and atretic follicles. It was decided that :

- the oocyte nucleus of healthy follicles should be in dictyate stage ; preovulatory follicles were excepted. According to Block (1951), degenerative changes usually occur simultaneously in the oocyte and the granulosa cells. An apparently intact nucleus may even sometimes be found in follicles in a state of marked degeneration ;

- objective but unquantifiable parameters unrelated to fixative artefacts would be used : irregular shape of the oocyte or follicle, wrinkled basement membrane ;

- as the pyknotic index in preovulatory follicles never exceeded 2 p. 100 , a follicle would be called healthy when its index was less than that percentage. We could not use the mitotic index as the only indicator of follicular quality because a high index was sometimes observed in atretic follicles, but it was used as a growth indicator once the follicle was judged to be healthy by its pyknotic index. 


\section{Results.}

As the mitotic activity of the granulosa cells indicates follicular growth rate, it was wondered if there was a relation between the mitotic index and menstrual cycle status or the state of follicular development. We thus calculated the mean mitotic index in healthy follicles for each follicular class and during each phase of the cycle (fig. 1). The mitotic index $(9.0 \pm 1.0$ p. 1000$)$ did not change during the menstrual
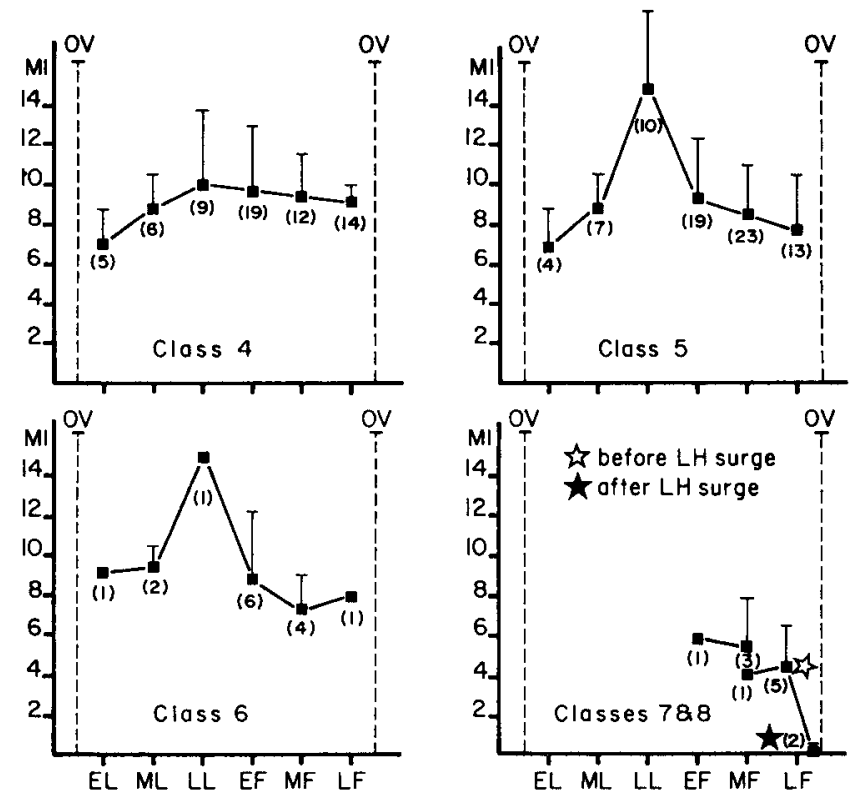

FIG. 1. - Evolution of the mitotic index (MI) in healthy follicles during the human menstrual cycle. OV : ovulation ; ( ) number of healthy follicles ; I Mitotic Index \pm SEM.

cycle in class 4 follicles. The mean mitotic index was the same in the following two groups, 5 and 6 (8.3 \pm 1.3 p. 1000 and $8.6 \pm 0.9$ p. 1000 , respectively), until late luteal phase, when it increased to $15.1 \pm 4.3$ and 15.1 p. 1000 , respectively. In the largest follicles (classes 7 and 8 ) the mitotic index was slightly lower until the LH surge (5.6 \pm 0.1 and $4.4 \pm 0.3$ p. 1000 respectively); after that, the index in class 8 follicles decreased sharply $(0.1$ p. 1000$)$.

Thus, the growth of human ovarian follicles, having between $75 \times 10^{3}$ and $375 \times 10^{3}$ granulosa cells and a diameter of 1 to $2 \mathrm{~mm}$, appeared to be constant during the menstrual cycle; for the follicles having a granulosa cell number between $0.37 \times 10^{6}$ and $2.4 \times 10^{6}$ there is a privileged period during the late luteal phase when growth appears accelerated. The large antral follicles of classes 7 and 8 were only present during the follicular phase ; their mitotic index first decreased slightly, then sharply after the LH surge.

To determine if there was any correlation between menstrual cycle status and ovarian follicle quality, we analyzed the pattern of healthy follicle percentages in 
each follicular class (including healthy and atretic follicles) during the entire menstrual cycle (fig. 2). This percentage parameter was selected because it was believed that an increase in the percentage of healthy follicles in one follicular class might indicate the ability of those follicles to pass from that class to the next. The majority (70 p. 100) of class 4 follicles was healthy; there was little change, except during the early luteal phase when all the follicles were healthy.

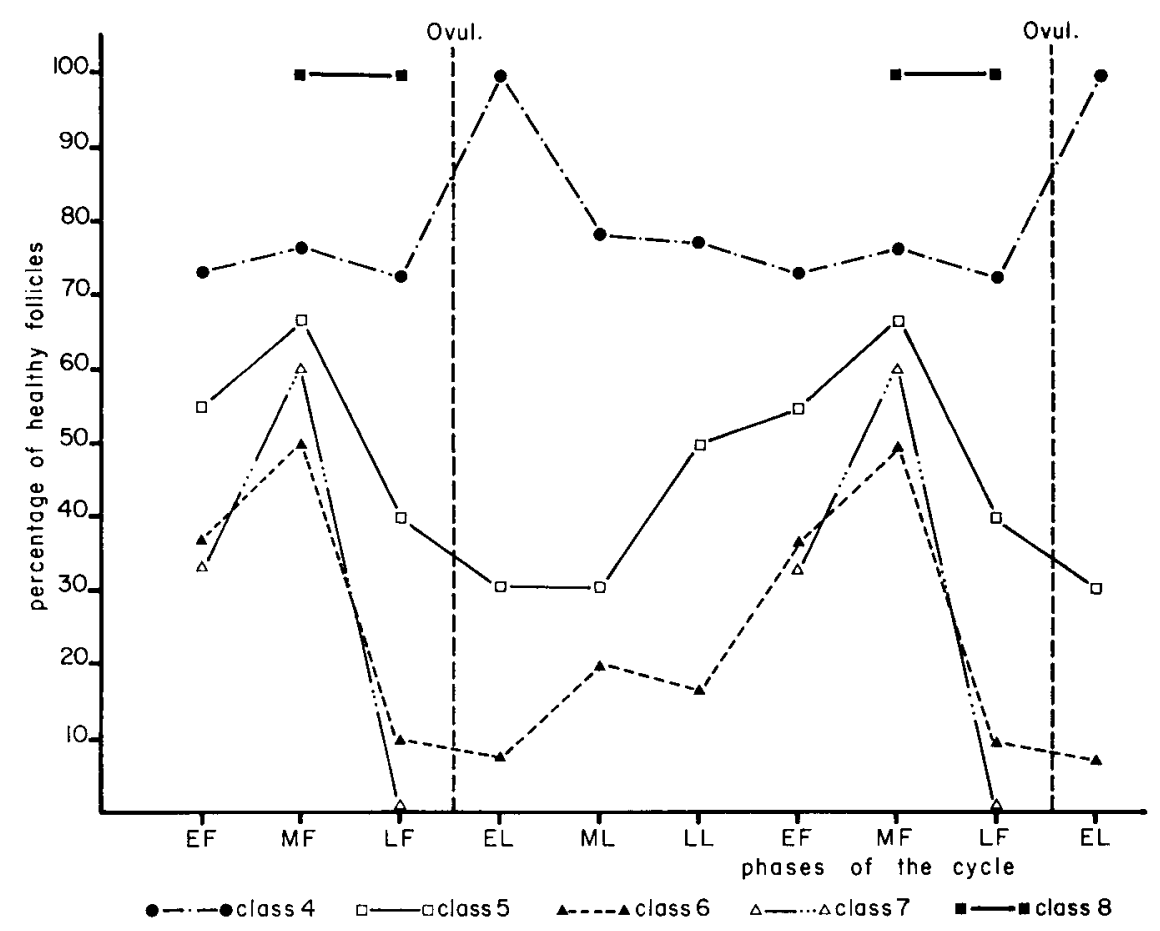

FIG. 2. - Qualifative evolution of medium and large antral follicles during the human menstrual cycle.

The kinetics of the following two follicular classes (5 and 6) were alike. The rise in the percentage of healthy class 5 follicles started between the mid and late luteal phases, whereas it started between the late luteal and early follicular phases in class 6 follicles.

The follicle of classes 6 and 7 were only present during the follicular phase. The percentage of healthy class 7 follicles increased between the early follicular and midfollicular phases, whereas the class 8 follicles (preovulatory) were always healthy during mid and late follicular phases.

\section{Discussion.}

Two models are usually proposed to describe folliculogenesis in mammals with a long ovarian follicle phase : (i) waves of follicular growth, as described by Smea- 
ton and Robertson (1971), Brand and De Jong (1973), Kruip and Brand (1975), Bherer ef al. (1976) in the ewe, Clark ef al. (1975) in the sow, Rajakoski (1960) in the cow, or (ii) continuous follicular growth with hormonally privileged periods, as reported by Marion and Gier (1971) and Mariana and Nguyen Huy (1973) in the cow and by Turnbull ef al. (1977) in the ewe.

Except during early luteal phase, the percentage of healthy class 4 follicles was unchanged; this might mean that there is a continual development of class 3 follicles into class 4 follicles.

The percentage of healthy class 4 follicles is always higher than that of class 5 , which in turn is higher than the class 6 percentage.

There is a parallel change in the percentage of healthy follicles in classes 5 and 6 during all the menstrual cycle. The increase in the percentage of healthy class 6 follicles would be followed by a decrease in the percentage of healthy class 5 follicles, if there is such a process as a wave of follicular growth.

Thus, these data do not seem to support any particular theory involving a wave of follicular growth. In women follicular development seems to be a rather continuous process.

The point at which the percentage of healthy follicles in each class begins to rise seems to be separated by a constant 4 to 5 -day interval, which may be the time required for a follicle to pass from one class to the next. This suggestion may be compared with that of Turnbull ef al. (1977) who think that a follicle usually needs about 5 days to grow from 0.5 to $2 \mathrm{~mm}$, and a further 4 days to reach $4.5 \mathrm{~mm}$.

In women, the time required to develop from a class 4 follicle $\left(75 \times 10^{3}\right.$ granulosa cells) into an ovulatory follicle (about $80 \times 10^{6}$ granulosa cells) is relatively long. These data are interesting, but we do not know the exact mitotic time (the time during which a mitotic figure is visible) of human granulosa cells. Some results on other species are available, but the values given are sometimes contradictory : 30 min (Lushbaugh, 1956), $26 \mathrm{~min}$ (Turnbull et al., 1977) and $1.5 \mathrm{~h}$ (Cahill, personal communication) for the ewe, and cannot be used. These details must be clarified before any more studies can be carried out on folliculogenesis in women.

If follicular growth is autonomous, the only limiting factor of follicular development being atresia, the percentage of healthy follicles in each class would not vary with the stage of the menstrual cycle.

During the late follicular phase, the majority of medium and large antral follicles (classes 5, 6, and 7) become atretic ; class 8 follicles are always healthy and ovulate at that time. Some authors have observed this process (women : Block, 1951 ; macaques : Koering, 1969 ; scws : Clark ef al., 1975 ; ewes : Turnbull ef al., 1977 after HCG injection). The decrease of the FSH level at the end of the mid-follicular phase certainly plays a great part in that involution, which could be aggravated some days later by the LH surge. Since FSH does not protect them against atresia and they are too small to ovulate, these medium and large follicles with LH receptors (sows : Kammerman and Ross, 1975) should become atretic at the time of the LH surge. Small class 3 and medium class 4 antral follicles have few or no LH receptors, and are insensitive to LH action; consequently, they would be privileged by the mid-cycle FSH surge.

The percentage of healthy class 5 and 6 follicles increased from the late luteal 
phase to the mid-follicular phase. This pattern resembles the curve of FSH secretion during that part of the menstrual cycle, as described by Taymor et al. (1972) and Sherman and Korenman (1975). FSH could have a stimulating effect on the follicles of these two classes, thus protecting them from atresia and stimulating their growth rate. These results may be compared with those of Turnbull et al. (1977), who observed in the ewe that follicles with a diameter between 1 and $2.5 \mathrm{~mm}$ grow fast.

In conclusion, the growth of medium and large antral follicles in women appears to be a continuous process with privileged periods of development. One of these occurs at the end of the luteal phase when class 5 and 6 follicles (with a diameter of 2 to $6 \mathrm{~mm}$ ) are protected against atresia and grow faster.

EEC Seminar on " Ovarian stimulation and egg quality in mammals », Luynes, France, octobre 1978.

Acknowledgements. - I wish to thank the heads and technicians of the pathological anatomy laboratories of several hospitals who helped in this study, especially those of the Antoine Béclère Hospital and the Institut Gustave Roussy. This work was funded by the Faculty of Medicine Paris-Sud, UER Kremlin-Bicêtre and the Institut National de la Santé ef de la Recherche Médicale.

Résumé. Afin de mieux comprendre la folliculogenèse dans l'ovaire humain, nous avons observé 370 follicules à antrum, moyens et grands. Ils provenaient des ovaires de 33 femmes âgées de 18 à 50 ans, prélevés à des moments variés du cycle menstruel. Ces follicules ont été rangés dans des classes en fonction du nombre de leur cellules de la granulosa. La distinction entre follicules sains et atrétiques repose sur l'analyse : de l'index pycnotique, de l'état nucléaire de l'ovocyte, de caractéristiques morphologiques de l'involution folliculaire. L'index mitotique moyen, ne varie pas avec le stade du cycle menstruel, sauf pendant la fin de la phase lutéale pour les follicules dont le nombre de cellules de la granulosa est compris entre $0,37 \times 10^{3}$ et $2,5 \times 10^{6}$.

Chez la femme, espèce à phase folliculaire longue, l'évolution qualitative des follicules à antrum, moyens et grands, ne semble pas compatible avec la théorie d'une vague de développement folliculaire. Nous suggérons, que la croissance folliculaire est un phénomène continu, avec les moments privilégiés pendant le cycle menstruel, plus particulièrement à la fin de la phase lutéale où certains follicules à antrum moyen sont moins sensibles à l'atrésie et croissent plus vite.

\section{References}

BHERER J., DUFOUR J., MATTON P., 1976. Destinée des deux plus gros follicules des ovaires de brebis à la suite de la destruction du plus gros follicule, et/ou de l'enlèvement du corps-jaune à deux moments du cycle. Can. J. Physiol. Pharmacol., 54, 7-11.

BLOCK E., 1951. Quantitative morphological investigations of the follicular system in women. Variations in the different phases of the sexual cycle. Acta endocrinol., 8, 33-54.

BOMSEL-HELMREICH O., 1976. The aging of gametes, heteroploidy and embryonic death. Int. J. Gynaec. Obstef., 14, 98-104.

BOMSEL-HELMREICH O., PAPIERNIK-BERKHAUER E., 1973. Qualité de l'ovulation et jumeaux monozygotes. Arch. franç. Péd., 30, 1096-1098.

BRAND A., de JONG W. H. R., 1973. Qualitative and quantitative micromorphological investigations of the tertiary follicle population during the cestrus cycle in sheep. J. Reprod. Fertil., 33, 431-439. 
BREITENECKER G., FRIEDRICH F., GOLOB E., PAVELKA R., 1975. Vergleichende morphologishe Untersuchungen der Wand von Bläschenfollikeln des menschlichen Ovars und deren Eizellen. Wien. Klin. Wschr., 87, 779-783.

CLARK J. R., FIRST N. L., CHAPMAN A. B., CASIDA L. E., 1975. Ovarian follicular development during the cestrus cycle in gilts following electrocautery of follicles. J. Anim. Sci., 41, 11051111.

ESHKOL A., LUNENFELD B., 1972. Gonadotropic regulation of ovarian development in mice, 335346, In SAXENA B. B., BELING C. G., GANDY H. M., Gonadotrophins, John Wiley and sons, New York.

FUGO N. W., BUTCHER R. L., 1970. Irregular menses-overripeness and fetal anomalies. J. Reprod. Med., 4, 79.

GOLDENBERG R. L., REITER F. O., ROSS G. T., 1973. Follicle response to exogenous gonadotrophins, an estrogen mediated phenomenon. Fertil. Steril., 24, 121-125.

GOVAN A. D. T., 1968. The human ovary in early pregnancy. J. Endocrinol., 40, 421-428.

GOVAN A. D. T., 1970. Ovarian follicular activity in late pregnancy. J. Endocrinol., 48, 235-241.

GREEN S. H., ZUCKERMAN S., 1951. Quantitative aspects of the growth of the human ovum and follicle. J. Anat., 85, 373-375.

KAMMERMAN S., ROSS J., 1975. Increase in numbers of gonadotropin receptors on granulosa cells during follicle maturation. J. clin. Endocrinol. Metab., 41, 546-550.

KOERING M. J., 1969. Cyclic changes in ovarian morphology in Macaca mulatta. Amer. J. Anat., 126, 73-101.

KRUIP T. A. M., BRAND A., 1975. Follicular growth during the normal cycle and after treatment with progestagens in the ewe. Ann. Biol. anim. Bioch. Biophys., 15, 191-206.

LUSHBAUGH C. C., 1956. Morphologic methods of defermining cellular doubling times : a review J. Histochem. Cytochem., 4, 499-507.

MARIANA J. C., NGUYEN HUY N., 1973. Folliculogenèse chez la vache. Ann. Biol. anim. Bioch. Biophys., 13, H.S., 211-221.

MARION G. B., GIER H. T., 1971. Ovarian and uterine embryogenesis and morphology of the nonpregnant female mammal. J. Anim. Sci., 32, suppl. 1, 24-47.

MESTWERDT W., MULLER O., BRANDAU H., 1977. Light and electron microscopic examinations on granulosa and theca of primordial, primary, secondary and resting tertiary follicles of human ovaries. Arch. Gynak., 222, 45-72.

RAJAKOSKI E., 1960. The ovarian follicular system in sexually mature heifers with special reference to seasonal, cyclical and left-right variations. Acta endocrinol., 52, 1-68.

SAURAMO H., 1954. The histology and function of the ovary from embryonic period to fertile age. Acta obstet. gynecol. scand., 33, Suppl. 2, 1-163.

SHERMAN B. M., KORENMAN S. G., 1975. Hormonal characteristics of the human menstrual cycle throughout reproductive life. J. clin. Invest., 55, 699-706.

SMEATON T. G., ROBERTSON H. A., 1971. Studies on the growth and atresia of graafian follicles in the ovary of the sheep. J. Reprod. Fertil., 25, 243-252.

STARUP J., VISFELDT J., 1974. Ovarian morphology in early and late human pregnancy. Acta obsfet. gynaecol. scand., 53, 211-218.

TAYMOR M. L., BERGER, THOMPSON I. E., KARAM K. S., 1972. Hormonal factors in human ovulation. Amer. J. Obstet. Gynecol., 111, 445-452.

TURNBULL K. E., BRADEN A. W. H., MATTNER P. E., 1977. The pattern of follicular growth and atresia in the ovine ovary. Aust. J. biol. Sci., 30, 229-241. 